\title{
Population dynamics and production of crustacean zooplankton in two mountain lakes in the Italian Alps (Lake Paione Superiore and Lake Malghette)
}

\author{
Marina MANCA*, Patrizia COMOLI and Valeria LENCIONI ${ }^{1)}$ \\ CNR Istituto Italiano di Idrobiologia - 28922 Verbania Pallanza, Italy \\ ${ }^{1)}$ Museo Tridentino di Scienze Naturali, V. Calepina, 14 - 38100 Trento, Italy \\ *e-mail corresponding author: m.manca@iii.to.cnr.it
}

\begin{abstract}
We estimated production of three populations of zooplanktonic crustacea from two lakes in the Italian Alps sampled within the EC-Project MOLAR (ENV-CT95-0007) "Measuring and modelling the dynamic response of remote mountain lake ecosystems to environmental change" (Lake Paione Superiore) and the EC-Guideline 78/659 "On the amelioration and the protection of freshwaters suitable for fish life" (Lake Malghette). The former is a fishless lake, while the latter, in addition to the native Phoxynus phoxynus, hosts populations of Salmo trutta fario and Oncorhynchus mykiss. The Allen curve method was used to estimate production of Acanthodiaptomus denticornis and Daphnia longispina in Lake Malghette and of Cyclops abyssorum tatricus in Lake Paione Superiore. Values of daily production of the three populations are similar to those found by other Authors in oligotrophic and high mountain environments.
\end{abstract}

Key words: zooplankton, secondary production, acidification, high mountain lakes

\section{INTRODUCTION}

Studies on secondary production are essential for the evaluation of energy and matter transfer along the trophic web, as well as the rationale management of aquatic ecosystems and the detection of the effects of pollution (Downing 1984). However, literature data reporting estimates of zooplankton production are scanty. In most cases, this is due to difficulties arising from the presence of polivoltine populations with continuous recruitment and overlapping generations which makes impossible to recognise different developmental stages. Having simplified biological communities, mountain lakes are suitable environments for the assessment of the transfer of matter and energy along the different trophic levels. Because of the extreme environmental conditions (very low nutrient concentrations, and large daily and seasonal fluctuations in water temperature and solar radiation) they have a relatively low number of species (Pechlaner 1971; Capblancq \& Laville 1983; Tilzer \& Schwartz 1976). Populations of crustacean zooplankton are often univoltine, so that cohorts are easily identifiable and production can be assessed by simple methods, like the Allen graphical method (1951).

Lake Paione Superiore and Lake Malghette were investigated within the EC-Project MOLAR (ENV-CT950007) (Measuring and modelling the dynamic response of remote mountain lake ecosystems to environmental change) and the EC- Guideline 78/659 (On the amelioration and the protection of freshwaters suitable for fish life), respectively. The former is an acidified $(\mathrm{pH}<6)$ and fishless lake; the latter, in addition to the native Phoxynus phoxynus, hosts populations of Salmo trutta fario and Oncorhynchus mykiss, which are yearly introduced.

\section{STUDY SITES}

Lake Paione Superiore (LPS) is situated in the Bognanco Valley, on the right side of the River Toce, a tributary of Lake Maggiore (Tab. 1).

Tab.1. Geographic and hydrochemical features of the two lakes.

\begin{tabular}{|c|c|c|c|}
\hline & & $\begin{array}{l}\text { L. Paione } \\
\text { Superiore }\end{array}$ & L. Malghette \\
\hline Altitude & $\mathrm{m}$ a.s.1. & 2269 & 1891 \\
\hline Longitude & East & $8^{\circ} 11^{\prime} 27^{\prime}$ & $1^{\circ} 38^{\prime} 3^{\prime \prime}$ \\
\hline Latitude & North & $46^{\circ} 10^{\prime} 26^{\prime \prime}$ & $46^{\circ} 16^{\prime} 12^{\prime \prime}$ \\
\hline Maximum depth & $\mathrm{m}$ & 10.5 & 10.6 \\
\hline Area & $\mathrm{km}^{2}$ & 0.014 & 0.954 \\
\hline Lake volume & $10^{6} \mathrm{~m}^{3}$ & 69 & $4.77 \times 10^{5} \mathrm{~m}^{3}$ \\
\hline $\mathrm{pH}$ & Mean & 5.6 & 5.9-7.5 \\
\hline Conductivity at $20^{\circ} \mathrm{C}$ & $\left(\mu \mathrm{S} \mathrm{cm}^{-1}\right)$ & 9.4 & 13 \\
\hline Total P & $\mu \mathrm{g}^{-1}$ & 4 & 4 \\
\hline Nitrate & $\mu$ eq $1^{-1}$ & 26 & $2-9 \mu \mathrm{g} \mathrm{l}^{-1}$ \\
\hline
\end{tabular}

It is a typical small, glacial cirque lake, relatively deep, with lowest water temperature under the ice-cover (about $1{ }^{\circ} \mathrm{C}$ ) and summer maxima around $13{ }^{\circ} \mathrm{C}$. Being the valley dominated by orthogneiss, the lakes has a low alkalinity, and is susceptible to acidification (Mosello et al. 1993). Values of $\mathrm{pH}$ are usually below 6, with a minimum of 5.5 units during the ice-melt. Nutrient and chlorophyll- $a$ concentrations are generally low, although abrupt increase can be observed during the ice cover phase (Cammarano \& Manca 1997).

Lake Malghette is the largest water body in the tonalite depression of the Presanella mountain group (Tab. 1). It is a glacial cirque, dimictic, oligotrophic lake (chlorophyll- $a$ about $3.6 \mathrm{mg} \mathrm{m}^{-3}$ during the summer period), slightly acidic, as typical for lakes located in sili- 
ceous basins $(\mathrm{pH}=5.9-7.5$; Flaim \& Lencioni 1996). Water temperature reaches maximum of about $20{ }^{\circ} \mathrm{C}$ in mid-summer. The surrounding vegetation is a mixture of alpine forest (Picea excelsa, Pinus cembra) and pasture.

\section{MATERIAL AND METHODS}

Zooplankton samples were collected from Lake Paione Superiore and Lake Malghette during the icefree period in 1996-1997 and 1994 -1995, respectively.

In Lake Paione Superiore a $200 \mu \mathrm{m}$ Epstein type plankton net (vertical hauls in the deepest point of the lake) was used for collecting large zooplankton (Daphnia, copepodites and adults of copepods) whereas nauplii where counted from integrated samples collected with a Ruttner bottle (MOLAR sampling protocol, 1996). A $100 \mu \mathrm{m}$ Epstein type net was used to sample zooplankton from Lake Malghette (vertical hauls in the deepest point). In most cases we counted the entire sample, recording the different taxa and developmental stages, eggs included. In addition, a sufficient number (100 at most) of organisms was measured from each sample.

Tab. 2. Population density and individual weight (carbon) of the different developmental stages of $\mathrm{A}$. denticornis and C. abyssorum tatricus from Lake Paione Superiore and Lake Malghette during 1997 and 1995 , respectively.

\begin{tabular}{|c|c|c|c|c|}
\hline & $\begin{array}{l}\text { A. den } \\
\text { ind } \mathrm{m}^{-3}\end{array}$ & $\begin{array}{l}\text { nticornis } \\
\mu \mathrm{g} \mathrm{C} \text { ind }^{-1}\end{array}$ & $\begin{array}{l}\text { C.abyssor } \\
\text { ind } \mathrm{m}^{-3}\end{array}$ & $\begin{array}{l}\mu m \text { tatricus } \\
\mu \mathrm{g} \mathrm{C} \text { ind }^{-1}\end{array}$ \\
\hline Nauplii & 2131 & 0.54 & 970 & 0.36 \\
\hline Copepodites & 1139 & 2.23 & 483 & 3.40 \\
\hline Adults & 588 & 4.22 & 338 & 7.14 \\
\hline
\end{tabular}

Biomass of naupliar stages (carbon, $\mu \mathrm{g}$ ) was obtained from biovolume, through approximation to geometrical solids, using formulas developed within the MOLAR project from original measurements of individuals in each sample (body length, maximum width, and dorso-ventral maximum width). Individual density was taken as $=1$ and carbon $(\mu \mathrm{g})=0.05$ fresh weight.

For copepodites and adults of copepods we calculated biomass (d.w.) from published equations based on direct measurements of body length (McCauley 1984), as follows:

- $\ln \mathrm{W}(\mu \mathrm{g})=2.34+2.98 \mathrm{lnL}(\mathrm{mm})$ for Acanthodiaptomus denticornis;

- $\ln \mathrm{W}(\mu \mathrm{g})=2.29+2.21 \operatorname{lnL}(\mathrm{mm})$ for Cyclops abyssorum;

- $\ln \mathrm{W}(\mu \mathrm{g})=6.26+3.05 \operatorname{lnL}(\mathrm{mm})$ for Holopedium gibberum.

We followed the recommendations of Bird \& Prairie (1985) in applying length/weight regression equations. Carbon was taken as $50 \%$ of dry weight.

For Daphnia longispina we calculated carbon individual content directly from body length, using the equation obtained from direct measurements of carbon (CHN elemental analyser; Manca et al. 1997).
Secondary production was evaluated using the Allen curve method (Allen 1951; Rigler \& Downing 1984) on $A$. denticornis and D. longispina from Lake Malghette and C. abyssorum tatricus from Lake Paione Superiore. The method, first used by Allen to calculate production in a New Zealand stream, is based on the statement that, provided the possibility to identify a cohort of individuals within a certain population, during the year we will find decreasing number of individuals (because of mortality) of increasing unitary body mass.

Tab. 3. Different types of production of $A$. denticornis form Lake Malghette between June and September 1995.

\begin{tabular}{lcc}
\hline Area & Type of production & $\begin{array}{c}\text { Carbon } \\
\left(\mu \mathrm{g} \mathrm{m}^{-3} \text { day }^{-1}\right)\end{array}$ \\
\hline ACDF & Total potential production & 101.93 \\
ABEG & Production of young & 30.14 \\
BCDE & Production of adults & 28.12 \\
ACDEG & Total production realised & 58.26 \\
AGEF & Unrealised production & 43.66 \\
\hline
\end{tabular}

\section{RESULTS AND DISCUSSION}

Two species make up the crustacean zooplancton community of Lake Paione Superiore, namely Daphnia longispina and Cyclops abyssorum tatricus (Cammarano \& Manca 1997). The former is the most important contributor to the total standing stock biomass and is responsible for the peak, usually in autumn (Fig. 1). A maximum of about $120 \mathrm{mg} \mathrm{m}^{-3}$ has been found in September 1996. Two cladocera (D. longispina and Holopedium gibberum) and two copepods ( $C$. abyssorum tatricus and Acanthodiaptomus denticornis) constitute the crustacean zooplankton of Lake Malghette (Flaim \& Lencioni 1996).

D. longispina is responsible for the summer peak, while, during spring, Holepedium gibberum dominates (Fig. 2). The contribution of copepods is not negligible all over the year; they reach their maximum biomass in August.

Data on population density of the different developmental stages of $A$. denticornis and of $C$. abyssorum tatricus (Tab. 2) suggests a univoltine succession from nauplii to copepodites and adults that allows the calculation of secondary production by the Allen method (Tabs 3 and 4). The different areas of the Allen curve (Figs 3 and 4) represent the different types of production.

The production realised by the populations of the two copepods is $57 \%$ of the potential one (Tabs 3 and 4). It is almost equally due to young and adults of A. denticornis (51.7\% and $48.3 \%$ respectively; Fig. 3) whereas adults give more contribution than young in $C$. abyssorum tatricus $(61.2 \%$ and $38.8 \%$, respectively; Fig. 4). In both populations, most of the unrealised production (mortality) occurs in the copepodite to adult stages $(75.02 \%$ in A. denticornis and $73.9 \%$ in C. abyssorum tatricus), which appear as the most vulnerable 


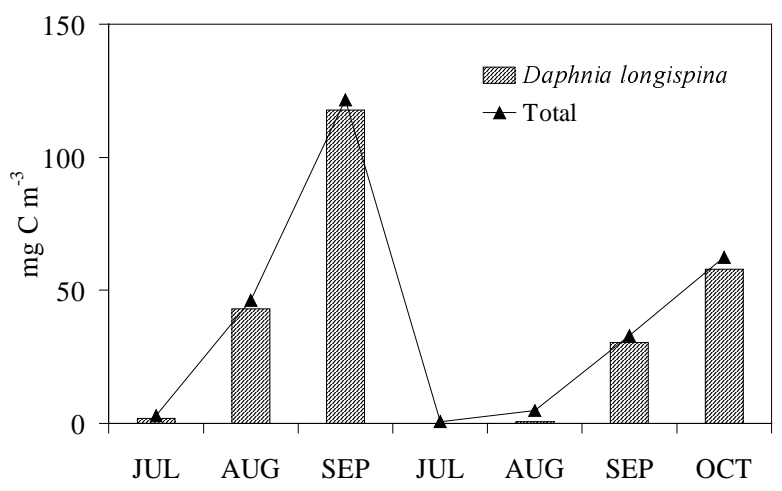

Fig. 1. Standing stock biomass of zooplanktonic crustacea of Lake Paione Superiore during 1996-1997.

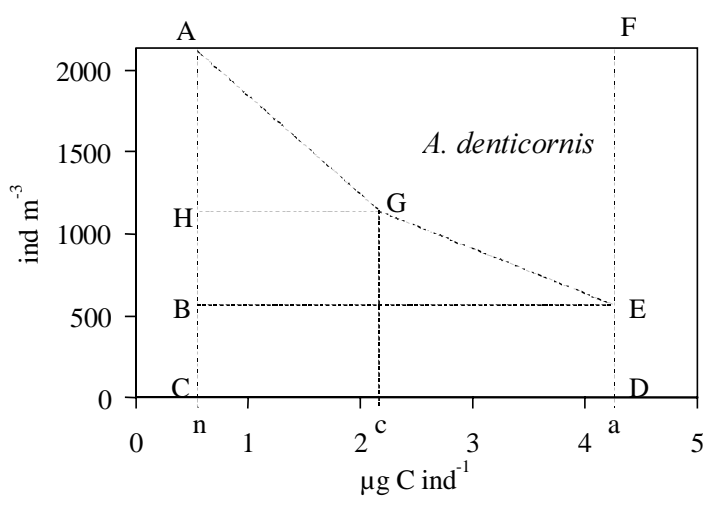

Fig. 3. Allen curve for the estimate of production of $A$. denticornis from Lake Malghette. For explanation of symbols see table 3 .

ones. Comparable values were found for the population of Arctodiaptomus alpinus from Lake Boden Inferiore (Alta Val Formazza) by de Bernardi et al. (1983). They calculated production in the period July-September 1979 with the same method (Allen 1951) and express the results as $\mu \mathrm{g}$ dry weight $\mathrm{m}^{-3}$ day $^{-1}$. Taking carbon as $50 \%$ dry weight, we obtain the following values (Tab. $5)$.

Tab. 4. Different types of production of C. abyssorum tatricus from Lake Paione Superiore between August and October 1997.

\begin{tabular}{lcc}
\hline Area & Type of production & $\begin{array}{c}\text { Carbon } \\
\left(\mu \mathrm{g} \mathrm{m}^{-3} \text { day }^{-1}\right)\end{array}$ \\
\hline ACDF & Total potential production & 84.3 \\
ABEG & Production of young & 18.6 \\
BCDE & Production of adults & 29.36 \\
ACDEG & Total production realised & 47.96 \\
AGEF & Unrealised production & 36.31 \\
\hline
\end{tabular}

The total production realised by A. alpinus is about half of the potential one; adults contribute more than young. Also in this case, mortality is mainly due to copepodite to adult stages $(67 \%$ of the total unrealised production).

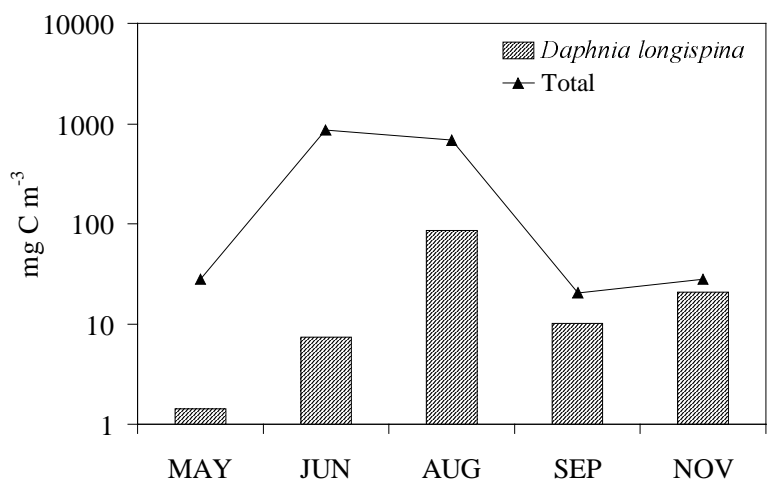

Fig. 2. Standing stock biomass of zooplanktonic crustacea of Lake Malghette during 1995.

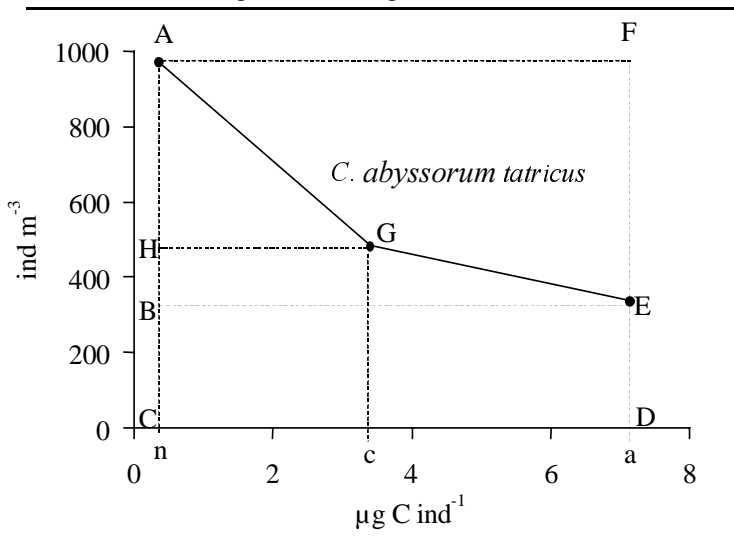

Fig. 4. Allen curve for the estimate of production of $C$. abyssorum tatricus from Lake Paione Superiore. For explanation of symbols see table 4.

Tab. 5. Different types of production of Arctodiaptomus alpinus from Lake Boden Inferiore during JulySeptember, 1979. From de Bernardi et al. (1983), modified.

\begin{tabular}{lcc}
\hline Area & Type of production & $\begin{array}{c}\text { Carbon } \\
\left(\mu \mathrm{g} \mathrm{m}^{-3} \text { day }^{-1}\right)\end{array}$ \\
\hline ACDF & Total potential production & 80.0 \\
ABEG & Production of young & 12.2 \\
BCDE & Production of adults & 28.5 \\
ACDEG & Total production realised & 40.7 \\
AGEF & Unrealised production & 36.0 \\
\hline
\end{tabular}

For the period August-September 1995 we also estimated production of the D. longispina population from Lake Malghette, where increasing individual biomass corresponded to decreasing numbers (Tab. 6), although being the initial population not strictly composed by new-born.

Total production represents $52 \%$ of the potential one, and is mainly done by preadults (Tab. 7). About $240 \mu \mathrm{g} \mathrm{C} \mathrm{m}^{-3}$ are daily available for planktivorous fish.

Ferrari \& Bellavere (1976) applying the method after Wright (1965) report a value of production of about $0.55 \mathrm{mg}$ d.w. $\mathrm{m}^{-3}$ for Daphnia longispina population in Lake Santo Parmense over the period June-November. 
This value results very close to that we have found in the population from Lake Malghette $(275$ and $256 \mu \mathrm{g} \mathrm{C}$ $\mathrm{m}^{-3}$ day $^{-1}$, respectively). Both are also similar to the average daily production reported for $D$. longispina in a lake of the Central Pyrenées (Rey \& Capblanq, 1975). In all cases, preadults give by far the highest contribution to the total production realised (Di Cola et al. 1978).

Tab. 6. Population density and individual weight (carbon) of preadults and adults of Daphnia longispina from Lake Malghette between August and September 1995.

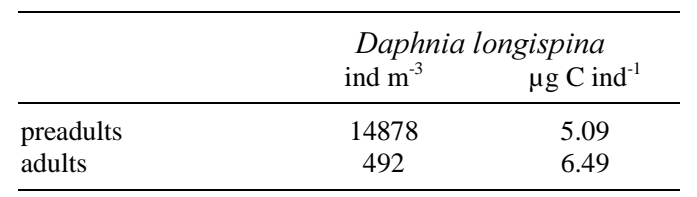

Tab. 7. Different types of production of Daphnia longispina from Lake Malghette during AugustSeptember, 1995.

\begin{tabular}{lc}
\hline Type of production & $\begin{array}{c}\text { Carbon } \\
\left(\mu \mathrm{g} \mathrm{m}^{-3} \mathrm{day}^{-1}\right)\end{array}$ \\
\hline Total potential production & 495.97 \\
Production of young & 239.80 \\
Production of adults & 16.40 \\
Total production realised & 256.20 \\
Unrealised production & 239.77 \\
\hline
\end{tabular}

\section{CONCLUSIONS}

$A$. denticornis and $C$. abyssorum tatricus populations from the two lakes have quite similar production values, fully comparable with those found in other alpine lakes (Lair 1977), but lower than those reported for subalpine and lowland lakes (Pederson et al. 1976).

Our estimate of production of $D$. longispina is very similar to that found in a lake from the Apennines (Ferrari \& Bellavere 1976 ); in both cases, production is mainly supplied by preadults. Our value of production from Lake Malghette was probably underestimated, as sampling date was too late in the season to allow us the finding of new-born hatched from ephippial eggs at the beginning of the biological cycle.

About half of the total potential production is realised by the three populations of copepods considered in the present work, as already observed in similar environments (de Bernardi et al. 1983).

\section{ACKNOWLEDGMENTS}

We thank Giovanna Flaim and Flavio Corradini (Istituto Agrario di San Michele all'Adige, Trento, Italy) for the laboratory assistance and providing of chemical data for Lake Malghette. We are also grateful to A. Lami and G.A. Tartari for field work in Lake Paione Superiore. The research on Lake Paione Superiore has been partially funded by the EC Project MOLAR (ENV4-CT95-0007).

Received: July 1998

Accepted: September 1998

\section{REFERENCES}

Allen, K.R. 1951. The Horokiwi stream. A study of a trout population. Fish. Bull. N.Z. Marine Dept., 10: 231 pp.

Bird, D.F. \& Y.T. Prairie. 1985. Practical guidelines for the use of zooplankton length-weight regression equations. $J$. Plankton Res., 7: 955-970.

Cammarano, P. \& M. Manca. 1997. Studies on zooplankton in two acidified high mountain lakes in the Alps. Hydrobiologia, 356: 9-109.

Capblancq, J. \& H. Laville. 1983. Le Lac de Port-Bielh (Pyrénées): exemple de fonctionnement d'un écosistème lacustre de haute montagne. In: Lamotte M. \& F. Bourlière (Ed.),. Structure et fonctionnement des écosystèmes limniques. Masson: 51-79.

de Bernardi, R., M. Brogi \& I. Origgi. 1983. Dinamica di popolazione e produzione di Arctodiaptomus alpinus in due laghi alpini d'alta quota: Laghi Boden, Alta Val Formazza 2340 s.l.m. Atti del $5^{\circ}$ Congresso AIOL: 407-416.

Di Cola, G., I. Ferrari \& . A. Ascolini. 1978. Estimation of the production of Daphnia longispina in a mountain lake. Boll. it. Zool., 45: 55-61.

Downing, J.A. 1984. Assessment of secondary Production: The First Step. In:, J:A: Downing \& F. Rigler (Ed.), A Manual on methods for Assessment of Secondary Productivity in Fresh Waters. Blackwell Scient. Publ.: 1-18.

Ferrari, I. \& C. Bellavere. 1976. Ricerche ecologiche su zooplancton e macrozoobenton del Lago Santo Parmense. Riv. Hydrobiol., XV: 3-46.

Flaim, G.\& V. Lencioni. 1996. The zooplankton population off a small alpine lake: Lake Malghette (Trentino, Italy). Atti del $12^{\circ}$ Congresso AIOL, 1: 325-334.

Lair, N. 1977. Biomasse et Production dans deux lacs du Massif Central français. Arch. Hydrobiol., 79: 247-273.

McCauley, E. 1984. The estimation of the abundance and biomass of zooplankton in samples. In: Downing J.A. \& F.H. Rigler (Ed.), A Manual on Methods for Assessment of Secondary Productivity in Freshwaters. Blackwell Scientific Publications:228-265.

Manca, M., P. Comoli \& T. Spagnuolo. 1997. Length-specific carbon content of the Daphnia population in a large subalpine lake, Lago Maggiore (Northen Italy): the importance of seasonality. Aquat. Sci., 59: 48-56.

MOLAR, 1996. Sampling protocol. Mimeography: $8 \mathrm{pp.}$

Mosello, R., A. Lami, P. Guilizzoni, M. Manca, A.M. Nocentini, A. Pugnetti, A Boggero, A. Marchetto, G.A. Tartari, R. Bettinetti, M. Bonardi \& P. Cammarano. 1993. Limnological studies on two sensitive lakes in the Central Alps (Lago Paione Superiore and Lago Paione Inferiore, Italy). Mem. Ist. ital. Idrobiol., 51: 127-146.

Pechlaner, R. 1971. Factors that control the production rate and biomass of phytoplankton in high mountain lakes. Mitt. Int. Ver. Limnol., 19: 125-145.

Pederson, G.L., E.B. Welch \& A.H. Litt. 1976. Plankton secondary productivity and biomass: their relation to lake trophic state. Hydrobiologia, 50: 129-144.

Rey, J. \& J. Capblancq. 1975. Dynamique des populations et production du zooplancton du Loc de Port-Bileh (Pyrenées Centrales). Annls. Limnol., 11: 1-45.

Rigler, F.H. \& J.A. Downing 1984. The calculation of Secondary Productivity. In:, J:A: Downing \& F. Rigler (Ed.), $A$ Manual on methods for Assessment of Secondary Productivity in Freshwaters. Blackwell Scient. Publ.: 19-58.

Tilzer, M. \& K. Schwartz. 1976. Seasonal and vertical patterns of phytoplankton light adaptation in high mountain lake. Arch. Hydrobiol. 77: 488-504.

Wright, J.C. 1965. The population dynamics and production of Daphnia in Canyon Ferry Reservoir, Montana. Limnol. Oceanogr., 10: 583-590. 